\title{
Disengagement from Violence and Terrorism: A Comparative Analysis of the Niger Delta, Nigeria, and the Balkans
}

John O. Tobor, Ph.D.

Email: tobor_nero@yahoo.com

Ardian Shajkovci, Ph.D.

Email: shajkovciardian@gmail.com

\section{Doi:10.5901/mjss.2016.v7n4p}

\begin{abstract}
A review of literature on the topic of radicalization and terrorism in the Balkans and in the Niger Delta, Nigeria, indicated a lack of empirical and systematic research on factors that motivate individuals to disengage from violence and terrorist organizations. This study fills that gap and adds to the global body of knowledge on disengagement from violence and terrorism. Drawing largely from their dissertation studies, the authors' intent for this comparative study was to stimulate debate around factors associated with disengagement from violence and terrorism. The study focused on addressing the factors that prompt residents of the Niger Delta, Nigeria, to renounce violence and a number of Kosovo's foreign fighters to disengage from terrorist groups fighting in the Syrian and the Iraq conflict. The conceptual framework for this study was built around social, psychological, and physical factors associated with disengagement from terrorism. The content analysis technique was applied to identify emergent themes. The findings generated from this study may enhance the readers understanding of the factors associated with disengagement from violence and terrorism, and potentially lead to the development of more efficient counterradicalization and counterterrorism policies in not only the Niger Delta, Nigeria, and the Balkans, but also globally.
\end{abstract}

Keywords: Balkans, foreign fighters, counter-radicalization, counterterrorism, Kosovo, Niger Delta, Nigeria, radicalization, terrorism, violence.

\section{Introduction}

A review of the literature failed to identify studies related to the issue of disengagement from violence in the Niger Delta, Nigeria, and from terrorist groups fighting in the Syrian and the Iraq conflict. Authors such as Disley, Weed, Reding, Clutterbuck, and Warnes (2012), Horgan (2009), and Rabasa (2013) explained that while there has been an abundance of research on radicalization and the processes by which individuals become radicalized, including to the point of engaging in violence, there was a limited amount of research on disengagement, or research on why individuals or groups abandon violence and terrorism. This study fills that gap and adds to the body of knowledge that focuses on disengagement from violence and terrorist activities.

The authors' conceptual framework was governed by Disley et al.'s (2012) "psychological, physical, and social factors" (p. 2) associated with abandoning Al Qaeda-influenced terrorist groups (See Table A1). Disley et al.'s model of disengagement from Al Qaeda-influenced terrorist groups complemented the findings of the literature reviewed. The conceptual framework offered an invaluable platform from which to launch the central research question and identify individual factors associated with leaving violence and terrorist groups in the Niger Delta region of Nigeria, Iraq, and Syria. The model served as glue that held together interlinked concepts and ideas, which, in combination, provided a deeper understanding of the processes associated with disengagement from violence and terrorist groups in the Niger Delta region of Nigeria, Iraq, and Syria. In the language of the conceptual framework utilized for this study, the findings indicated that psychological and social factors have played an important role in individuals' decision to abandon violence and terrorist organizations. 
Table A1: Conceptual Model (Individual Factors)

\begin{tabular}{|c|c|}
\hline Psychological Factors & Social Factors \\
\hline $\begin{array}{l}\text { - } \quad \text { Disillusionment with how the group operates internally. } \\
\text { - } \quad \text { Disillusionment with group ideology and strategy. } \\
\text { - } \quad \text { Group involvement in criminal activity (i.e. contrary to } \\
\text { - } \quad \text { ideological/religious beliefs). } \\
\text { - } \quad \text { Hardship with poor nutrition. } \\
\text { - } \quad \text { Fear of violence. } \\
\text { - } \quad \text { Feelings of remorse (e.g. attacking civilians). } \\
\text { - Intimidation by group members. } \\
\text { - Inadequate compensation. } \\
\text { - } \quad \text { Government security measures. }\end{array}$ & $\begin{array}{l}\text { - } \quad \text { Ties to family and friends outside the organization. } \\
\text { - } \quad \text { Relationship with institutions. } \\
\text { - Neighborhood effects. } \\
\text { - } \text { obanging personal priorities (e.g., live a settled life, } \\
\text { and children, etc.). }\end{array}$ \\
\hline Physical Factors & Factors Preventing Disengagement \\
\hline $\begin{array}{l}\text { - } \text { Change of role within the organization. } \\
\text { - Imprisonment. } \\
\text { - } \quad \text { Expulsion from the group. } \\
\text { - } \text { Wounded on the battlefield. }\end{array}$ & $\begin{array}{l}\text { - In-group solidarity. } \\
\text { - Harsh punishment for exit. } \\
\text { - Lack of protection in the out-of-group environment. } \\
\text { - Fear of imprisonment. } \\
\text { - No viable life alternatives. }\end{array}$ \\
\hline
\end{tabular}

\section{Methodology}

Tobor (2014) and Shajkovci (2015) relied on qualitative methods. This method was used because the main goal of their respective studies was to understand collective experiences of a particular cultural group, specifically the meanings and values that such groups portray. A realist ethnographic research was utilized in both studies. The ethnographic qualitative approach helped to closely examine the type of meaning the study participants attached to their social and political environments. Face-to-face interviews served as a primary data collection method. Semi-structured and openended interview questions were employed. The interview questions followed a consistent wording structure and were devoid of any leading questions. Secondary sources, such as court reports, published testimonies and analytic reports, were also consulted. Formal and informal observations were conducted to generate a better understanding of the phenomenon under study in order to report factual and descriptive data. Observational field notes and reflexive journals were utilized to record observations.

The purposeful sampling strategy was used to recruit study participants. While Tobor (2014) utilized 20 exmilitants from the Urhobo speaking origin as its study participants, Shajkovci (2015) collected data from 12 government officials in Kosovo with direct knowledge on the issue of disengagement from terrorist groups in Iraq and Syria, such as prosecutors and law enforcement officials. The process took months of intermittent fieldwork and data collection on the ground. The conventional and summative content analysis techniques were used to analyze the collected data. The conventional content analysis technique was helpful in generating coding categories from the actual text data, while the summative content helped with the detection of important words and concepts within the text, which was crucial to generating patterns, comparisons, and contextual interpretations (Hsieh \& Shannon, 2005). In combination, the two allowed to ascertain relationships among the coded data as well as draw inferences.

\section{Brief Historical Background of Kosovo's Safety and Security Landscape}

The 2011 attack on the U.S. Embassy in Sarajevo, Bosnia, by a young Wahhabi adherent (Sito-Sucic, 2011), a deadly explosion that killed several Israeli tourists in Bulgaria in July 2012 (Kulish \& Schmitt, 2012), and a number of recent arrests for terrorism-related offenses (British Broadcasting Corporation, 2014; United States Department of State, 2014) served as a testament to a growing threat of Islamic extremism and terrorism in the Balkans. The recent literature highlighted the influence that radical Islamic ideologies, such as Salafism, Wahhabism, Islamism, and Takfir ideology, depending on the perspective, have continued to amass over predominantly young Muslims in the Balkans (Gibas-Krzak, 2013; Gutaj, 2014; Hide, 2014; Kursani, 2015; Schwartz, as cited in Mirchevski, 2013; Tziampiris, 2009; Veljovski, 2011). When analyzing the roots of religiously-driven extremism and violent motivations in the Balkans, it is not at all uncommon for certain scholars and reporting circles on the topic to often conflate the aforementioned ideological terms and discount 
fundamental nuances (e.g. Islamism, as a political movement v. Salafism, often apolitical and pacifist in nature, etc.) inherent in them (Delong-Bas, 2007; Hasan, 2006).

The recent arrests of a number of Balkan Muslim extremists in particular have raised concerns over the continued influence of foreign radical Islamic ideological networks and groups on the indoctrination processes of predominantly young Balkan Muslims (Tema, 2014). Bardos (2014), Gutaj (2014), and Kursani (2015) explained how a small number of Balkan Muslim extremists have followed in the footsteps of foreign fighters fighting alongside terrorist groups such as AlNusra and the Islamic State in Iraq and the Levant (ISIL) in Syria. According to Kursani (2015), as of mid-January 2015, Kosovo had 232 confirmed cases of foreign fighters suspected of joining militant organizations in Iraq and Syria, the majority of whom had joined the conflicts of Syria in 2013 and during the consolidation period of the Islamic State of Iraq and the Levant (ISIL). Based on a per capita basis, Kosovo has the most representation of foreign fighters in Iraq and Syria of any European nation. According to the data, in proportion to its Muslim population, however, Kosovo has the lowest representation of foreign fighters in Iraq and Syria among the 22 western states included in Kursani's (2015) study.

While a discussion on the origins of religious and ideological extremism in the Balkans, including in Kosovo, remains beyond the scope of this article, specifically religious and ideological extremism that emerged following the breakup of Yugoslavia and the collapse of communist regime in Albania in the early 1990s, Shajkovci (2015) stressed the dangers of often inflated and sensationalist accounts that exaggerate the threat of religious and ideological extremism in the Balkans. The Balkans remains largely secular with an overwhelming majority of Balkan Muslims who openly oppose involvements with terrorist groups in Iraq and Syria. Although not necessarily an imminent threat, several authors stressed the fear of anticipated return and the possible threat posed by such returning individuals or groups to their home countries (Bardos, 2014; Gutaj, 2014; Seffers, 2014). Not only have such realities created concerns at the highest levels of the Balkan political order, but they have also prompted important changes in legal reforms and legislation. In response to such threats, governments in the region have introduced a series of safety and security measures, predominantly focused on intelligence and law enforcement components (de Kerchove, as cited in Nomikos, 2014).

\section{Brief Historical Background of the Niger Delta Crisis}

Several researchers defined the Niger Delta region to include nine states, namely Abia, Akwa Ibom, Bayelsa, Cross River, Delta, Edo, Imo, Ondo and Rivers State (Badmus, 2010; Idowu, 2012; Odoemene, 2011; Okpo \& Eze, 2012; Olankunle, 2010). Badmus (2010) described the Niger Delta region as a zone of demographic minorities comprised of different ethnic tribes that include the Urhobos, the ljaws, Ibibios, Kalabari, Itshekiris, Efiks, Isoko, Nembe, Ndom, Andoni, and Ikwerre (Badmus, 2010; Okpo \& Eze, 2012). The region has a population of about 28.9 million people (Ogege, 2011; Okpara, 2012). Anele and Omoro (2012) asserted that oil revenue derived from the Niger Delta region accounts for more than 90 percent of Nigeria's wealth. In spite of the Niger Delta's dominant contribution to the national economy, the general state of the region is characterized by extreme poverty, environmental pollution, total neglect, high unemployment, underdevelopment, and inadequate infrastructure (Amadi \& Abdullah, 2012; Obi, 2010). Akpan, Eteng, Ering, and Abia (2012) argued that the destruction that petroleum processing and production has inflicted on the inhabitants of the region, including their sources of livelihood, is a central factor in understanding the conflict dynamics in the Niger Delta region. In the early 1990s, these problems led to a violent uprising against oil exploration. In 2009, the government of Nigeria attempted to end the uprising by implementing an amnesty program for the militants that was designed to address the region's problems (Odubo \& Tobor, 2016).

Shajkovci (2015) explained that acts of terrorism in the Balkans are treated as criminal offenses and are addressed through legal means and security institutions. While the government of Kosovo has also introduced a number of programs to address the issue of radicalization and extremism, in 2009 the government of Nigeria introduced the amnesty program to address the incessant unrest in Niger Delta, Nigeria, necessitated by extreme poverty, lack of basic infrastructural amenities, and destruction to source of livelihood (Akanji \& Oyitso, 2012; Idowu, 2012; Odubo \& Tobor, 2016; Ogege, 2011; Republic of Kosovo, 2012).

\section{The Study Findings and Discussion}

The comparative analysis of Tobor (2014) and Shajkovci (2015) revealed certain themes common to both studies. For instance, the available evidence based on participant responses in Tobor (2014) and Shajkovci (2015) indicated that engagement in criminal activity, fear of violence, feelings or remorse, and the influence of family and friends were the most commonly cited reasons for disengagement from violence and terrorist groups. Tobor (2014) noted that the responses from the participants in his study indicated that most of them chose to become militants because of their 
commitment and loyalty to the interests of their people. Further affirmation of this fact may be viewed from their cultural background as a people who cherish cultural values that include a sense of community.

While commitment to a group may be precipitated by a sense of belonging, the findings of Shajkovci (2015) indicated that a number of Kosovar extremists engaged with the terrorist groups in Iraq and Syria felt disillusioned with the group ideology, the group overall strategic path, and the groups' misinterpretation of Islam, which was a significant reason for disengaging from terrorism. Tobor (2014) identified the negative impact of public opinion as a reason why the study participants decided to renounce violence, also thematically relatable to Shajkovci's (2015) findings, including the global literature on the topic (Curcio, 2006; Demant et al., 2008; Garfinkel, 2007; Jacobson, 2008, 2010), and also for fear of being stigmatized as a reason why they rarely want to reveal their true identity as ex-militants.

Another similar theme common to Tobor (2014) and Shajkovci's (2015) findings is that, in certain cases, the data collected indicated that family and friends have played a crucial role in encouraging disengagement from violence and terrorist groups. According to Shajkovci (2015), the findings of his research indicated social ties to family and friends outside the group appear to have influenced disengagement from terrorist groups. In agreement with this view, Tobor (2014) posited that a majority of the ex-militants interviewed cited the need to ensure that their children do not grow up as orphans as a reason why they took advantage of the introduction of the amnesty program as an opportunity to renounce violence.

Governments in particular do have a significant role to play with regards to individual or group disengagement from violence and terrorism. In agreement with this view, Tobor (2014) posited that the introduction of the amnesty initiative witnessed a reduction in the crime rate and violence that is characteristic of the Niger Delta region. The findings of Tobor (2014) are consistent with the literature reviewed. For instance, several researchers maintained that the Nigerian government introduced the Amnesty program in 2009 as a means to create an enabling and peaceful environment to address the developmental issues and problems of the Niger Delta region (Akanji \& Oyitso, 2012; Idowu, 2012; Odubo \& Tobor, 2016; Ogege, 2011; Oluwaniyi, 2011). Similarly, Shajkovci (2015) identified other government measures, including pardons and prisoner dispersion as a means of minimizing group control over individuals in isolated conditions. The amnesty program introduced by the Nigerian government also served as a presidential pardon to those who agreed to surrender their arms and enroll in the amnesty program (Tobor, 2014).

\section{Significance of the Study}

The literature reviewed indicated a lack of empirical and systematic research on factors that motivate individuals to disengage from violence and terrorism (Disley et al., 2012; Fink \& Hearne, 2008; Rabasa, 2013). Identifying the manner in which individuals not only become involved in violence and terrorism but also disengage from terrorism may provide an opportunity for safety and security agencies in Kosovo, including the Balkans in general, and Nigeria to advance effective policy initiatives that facilitate and promote disengagement from violence and terrorism. To a certain extent, such initiatives may also restrict the involvement in terrorist organizations in the first place (Horgan, 2009). Understanding such processes and motivating factors may be necessary as they may have a "delegitimizing effect on violent radical groups in the eyes of the public" (Fink \& Hearne, 2008, p. 1).

Development of such country-specific narratives of disengagement as opposed to relying only on the experiences of other countries may provide safety and security officials on the ground vital information they need to be more effective in their counter-radicalization and counterterrorism efforts. Moreover, while disengagement does not necessarily equate to deradicalization (Taylor \& Horgan, 2011), such understandings may lead to initiatives that could affect cognitive changes in individuals as well as mitigate the risk of involvement in future terrorist activities (Taylor \& Horgan, 2011). Findings from the study may also aid global counterterrorism efforts. It is noteworthy to mention that the research study of Shajkovci (2015) instigated the first empirical study on such topic focusing on the Balkan Muslims. Similarly, the study of Tobor (2014) was the first empirical study that focused on culture and the amnesty program in Niger Delta, Nigeria.

\section{Conclusions}

This comparative study served to identify the reasons why individuals or groups disengage from violence and terrorism, specifically from the perspective of a number of Balkan Muslim foreign fighters engaged with terrorist groups in Iraq and Syria and the perspective of militants of the Niger Delta, Nigeria. The findings of both studies, in particular, highlighted the crucial role of social factors in individuals' decision to abandon violence and terrorist organizations. The data generated from interviews conducted in the studies offer an invaluable avenue for future exploration of the topic. Future researchers could further expand on this topic by focusing on the issue from the perspective of different Balkan countries. In terms of 
positive social change, identifying the manner in which individuals not only become involved in terrorism but also disengage from terrorism could provide an opportunity for safety and security agencies in the Balkans and in the Niger Delta, Nigeria, to advance effective policy initiatives that facilitate and promote disengagement from violence and terrorism. Such understanding may reveal important cross-cultural and cross-country similarities in patterns and processes of radicalization and consequently strengthen global counterterrorism efforts as well.

\section{References}

Akanji, T. A., \& Oyitso, M. (2012). Consumers' views of the strategies for promoting peace and sustainable development in the Niger Delta region. Review of European Studies, 4(2), 168-174. doi:10.5539/res.v4n2p168

Akpan, F., Eteng, F., Ering, S.O., \& Abia, R. P. (2012). An empirical analysis of the Niger Delta crisis in Nigeria and the way forward. European Journal of Social Sciences, 33(3), 364-373.

Amadi, B. O., \& Abdullah, H. (2012). Poverty alleviation through corporate social responsibility in Niger Delta, Nigeria. Asian Social Science, 8(4), 57-67. doi:10.5539/ass.v8n4p57

Anele, K. A., \& Omoro, J. (2012). Mobilizing the militants in the Niger Delta for national development: Prospects and Challenges. Journal of International Diversity, 2012(1), 107-122.

Badmus, I. A. (2010). Oiling the guns and gunning for oil: Oil violence, arms proliferation and the destruction of Nigeria's Niger Delta. Journal of Alternative Perspectives in the Social Sciences, 2(1), 323-363.

Bardos, N. G. (2014). Jihad in the Balkans: The next generation. World Affairs, 177(3), 73-39. Retrieved from http://www.ebscohost.com

British Broadcasting Corporation. (2014). Kosovo police net Iraq and Syria "militant suspects." Retrieved from http://www.bbc.com/news/world-europe-28739084

Curcio, S. (2006). The dark side of jihad: How young men detained at Guantanamo assess their experiences. In C. Benard (Ed.). Future for the young: Options for helping Middle Eastern youth escape the trap of radicalization (pp. 50-64). Santa Monica, CA: RAND Corporation.

Delong-Bas, N. (2007). Wahhabi Islam: From revival and reform to global jihad. New York, NY: Oxford University Press, Inc.

Demant, F., Slootman, M., Buijs, F. \& Tillie, J. (2008). Decline and disengagement: An analysis of processes of deradicalisation. Retrieved from http://www.dare.uva.nl

Disley, E., Weed, K., Reding, A., Clutterbuck, L., \& Warnes, R. (2012). Individual disengagement from Al-Qa'ida-influenced terrorist groups. Santa Monica, CA: RAND Corporation.

Fink, C. N., \& Hearne, B. E. (2008). Beyond terrorism: Deradicalization and disengagement from violent extremism. New York, NY. International Peace Institute.

Garfinkel, R. (2007). Personal transformations: Moving from violence to peace. (Report No. 186). Retrieved from United States Institute of Peace website: http://www.usip.org/files/resources/sr186.pdf

Gibas-Krzak, D. (2013) Contemporary terrorism in the Balkans: A real threat to security in Europe. The Journal of Slavic Military Studies, 26(2), 203-218. doi:10.1080/13518046.2013.77986

Gutaj, P. (2014). The Balkans and Syria's civil war: Realities and challenges. Retrieved from http://www.uiliria.org/iir/file/20_PerparimGutaj_IIR_2014_1.pdf

Hasan, N. (2006). Laskar jihad: Islam, militancy, and the quest for identity in post-new order indonesia. Ithaca, NY: Cornell Southeast Asia Program Publications.

Hide, E. (2014). Islamic extremism in the Balkans as a geopolitical instrument. 126 Mediterranean Journal of Social Sciences, 5(6), 375380. doi:10.5901/mjss.2014.v5n6p375

Horgan, J. (2009). Individual disengagement: A psychological analysis. In T. Bjorgo \& J. Horgan (Eds.). Leaving terrorism behind (pp.1730). New York, NY: Routledge.

Hsieh, H., \& Shannon, E. S. (2005). Three approaches to qualitative content analysis. Qualitative Health Research, 15(9), 1277-1288. doi:10.1177/1049732305276687

Idowu, O. F. (2012). Niger Delta crises: Implication for society and organizational effectiveness. British Journal of Arts and Social Sciences, $7(11)$.

Jacobson, M. (2008). Why terrorists quit: Gaining from Al- Qa'ida's losses. CTC Sentinel, 1(8), 1-4. Retrieved from http://www.ebscohost.com

Jacobson, M. (2010). Terrorist dropouts: Learning from those who have left. Washington, DC: Washington Institute for Near East Policy. Retrieved from http://www.worldcat.org

Kulish, N. \& Schmitt, E. (2012). Hezbollah is blamed for attack on Israeli tourists in Bulgaria. Retrieved from http://www.nytimes.com/2012/07/20/world/europe/explosion-on-bulgaria-tour-bus-kills-at-least-five-israelis.html?pagewanted=all

Kursani, S. (2015). Report inquiring into the causes and consequences of Kosovo citizens' involvement as foreign fighters in Syria and Iraq. Pristina, Kosovo: Kosovar Center for Security Studies.

Mirchevski, N. (2013). Moderate Balkan Muslims are targeted by Wahhabis and the Muslim Brotherhood. Retrieved from http://www.islamicpluralism.org/2303/moderate-balkan-muslims-are-targeted-by-wahhabis

Nomikos, N. J. (2014). Balkan-Mediterranean intelligence-sharing cooperation and counterterrorism in Greece. Retrieved from http://www.rieas.gr/images/nomikos14.pdf 
Obi, C. I. (2010). Oil extraction, dispossession, resistance, and conflict in Nigeria's oil- rich Niger Delta. Canadian Journal of Development Studies, 30(1-2), 219-236.

Odoemene, A. (2011). Social consequences of environmental change in the Niger Delta of Nigeria. Journal of Sustainable Development, 4(2),123-135. doi:10.5539/jsd.v4n2p123

Odubo, F. E. and Tobor, J. O. (2016). Nigeria's amnesty program: An educational and cultural perspective. African Educational Research Journal, 4(1), 1-7.

Ogege, S. O. (2011). Amnesty initiative and the dilemma of sustainable development in the Niger Delta region of Nigeria. Journal of Sustainable Development, 4(4), 249-258. doi: 10.5539/jsd.v4n4p249

Okpara, C. I. (2012). Right to a clean and healthy environment: The panacea to the Niger Delta struggle. Journal of Politics and Law, 39. doi:10.5539/jpl.v5n1p3

Okpo, O. C., \& Eze, R. C (2012). Vandalization of oil pipelines in the Niger Delta region of Nigeria and poverty: An overview. Studies in Sociology of Science, 3(2), 13-21. doi:10.3968/j.sss.1923018420120302.2950

Olankunle, M. F. (2010). Women's response to the question of development in the Niger Delta, Nigeria. Journal of Comparative Research in Anthropology and Sociology,1(1), 133-149.

Oluwaniyi, O. O. (2011). Post-amnesty programme in the Niger Delta: Challenges and prospects. Conflict Trends, 4, 46-54.

Rabasa, M. A. (2013). The deradicalization of Islamists. Retrieved from http://www.journal.georgetown.edu/the-deradicalization-ofislamists-by-angel-m-rabasal

Republic of Kosovo. (2012). Republic of Kosovo national strategy against terrorism. Retrieved from http://www.mpbks.org/repository/docs/Strategy_for_Counter_Terrorism_2012-2017_eng.pdf

Seffers, G. (2014). Lone wolf terrorists prowl the Balkans. Retrieved from http://www.afcea.org/content/?q=node/12763

Shajkovci, A. (2015). Radicalization and safety and security in the Balkans: An Ethnographic Study. Doctoral dissertation, Walden University, Minneapolis, Minnesota, U.S.A. ProQuest, UMI Dissertations Publishing, 3740705.

Sito-Sucic, D. (2011). Gunman attacks U.S. embassy in Bosnia. Retrieved from http://www.reuters.com/article/2011/10/28/us-bosniausa-embassy-idUSTRE79R66F20111028

Taylor, M., \& Horgan, J. (2011). Disengagement, de-radicalization, and the arc of terrorism. In R. Coolsaet (Eds.). Jihadi terrorism and the radicalisation challenge (pp. 173-187). Burlington, VT: Ashgate Publishing Company.

Tema. (2014). Arrestohen tre xhihadiste kosovare, planifikonin sulm ndaj nje baze te KFOR-it. Retrieved from http://www.gazetatema.net/web/2014/10/30/arrestohen-tre-xhihadiste-kosovare-planifikonin-sulm-ndaj-nje-baze-te-kfor-it/

Tobor, J. O. (2014). Urhobo culture and the amnesty program in Niger Delta, Nigeria: An ethnographic case study. Doctoral dissertation, Walden University, Minneapolis, Minnesota, U.S.A. ProQuest, UMI Dissertations Publishing, 3645926.

Tziampiris, A. (2009) Assessing Islamic terrorism in the Western Balkans: The state of the debate. Journal of Balkan and Near Eastern Studies, 11(2), 209-219. doi:10.1080/19448950902921143

United States Department of State. (2014). Country reports on terrorism 2013 - Kosovo. Retrieved from http://www.refworld.org/docid/536229df4a.html

Veljovski, G. (2011). An evaluation of the intensity of radical Islam in the Balkans and the assessment of its level of threat for European security. School of Advanced Military Studies. Fort Leavenworth, Kansas. 